\begin{tabular}{c|c}
\multirow{2}{*}{ EESD'15 } & The $7^{\text {th }}$ International Conference on Engineering Education for Sustainable Development \\
\cline { 2 - 2 } & Vancouver, Canada, June 9 to 12, 2015
\end{tabular}

\title{
DEVELOPMENT OF A CASE-BASED TEACHING MODULE TO IMPROVE STUDENT UNDERSTANDING OF STAKEHOLDER ENGAGEMENT PROCESSES WITHIN ENGINEERING SYSTEMS DESIGN
}

\author{
Carli D. Flynn ${ }^{1,2}$, Mallory Squier ${ }^{1}$, and Cliff I. Davidson ${ }^{1}$ \\ ${ }^{1}$ Syracuse University, USA \\ 2 cflynn@syr.edu
}

\begin{abstract}
This paper introduces a case-based teaching module designed to increase student understanding of the importance of stakeholder engagement processes in the design of complex engineering systems. The teaching module makes use of a case study on past technology adoption and environmental injustices related to stormwater management plans in Onondaga County, NY. The module begins with a review of the history of events in the County, including social unrest when the needs of certain stakeholder groups were ignored. Students are then divided into groups, each representing an assigned stakeholder community. The students predict what engineering designs will most directly affect their stakeholder group and how each design solution may impact other groups. An assessment tool is used to gauge the students' perceptions of stakeholder engagement and engineering design after the teaching module. Results demonstrate that the module effectively increased student understanding of the complexities related to the engineering design process, particularly stakeholder engagement activities. The module also improved student motivation and interest in course material. These results provide insights for instructors seeking effective ways to bring stakeholder concerns into the classroom.
\end{abstract}

\section{INTRODUCTION}

Engineers are now being tasked with understanding the broader social, economic, and environmental implications of their work (Allenby et al., 2009). This requires changes in the education of engineers to think holistically and incorporate a complexity of new constraints in practice (Davidson et al., 2007). It is unrealistic to expect students with little "real-world" experience to understand these complexities through traditional instructional methods. Instead, introducing pedagogical elements such as historical context, decision-making, and ethics into the classroom can aid in the development of "post-conventional" engineers. This term has been used to describe engineers who have a sense of autonomy in their work and see and treat engineering work as requiring complex decision making and social responsibility (Nair, 1997).

This paper proposes that case-based simulation modules can better prepare engineering students to appreciate the complex situations they will encounter on the job. For this study, a stakeholder simulation exercise on selecting management practices for stormwater control was developed to help civil and environmental engineering students learn to apply sustainability concepts and principles. The module makes use of active and collaborative teaching pedagogies within a learning cycle framework. 


\subsection{Context and Motivation for Module Development}

The module was originally designed for the course Sustainability in Civil and Environmental Systems, a sophomore core course for Civil and Environmental Engineering majors at Syracuse University. When this study was conducted in the spring semester of 2014 there were 76 students in the class. The course encompasses a broad range of topics integrating sustainability into a traditional introductory environmental engineering course with the following primary instructional objectives:

A. Introduce principles of sustainability and systems as applied to the natural and built environments;

B. Provide skills necessary for quantitative assessments of civil and environmental engineering problems;

C. Use principles developed in class to evaluate and solve complex open-ended environmental problems and communicate the results of the analysis.

The course material is primarily covered in lectures, or a combination of lecture and in-class problem solving activities. The course is divided into 4 topic areas: population, energy, water, and air. Within the water unit, topics include water contaminants, physical properties of water and the hydrologic cycle, municipal water and wastewater, and urban water management. The last topic covers green vs. gray methods of controlling urban stormwater runoff.

\subsection{Theoretical Background}

Active learning methods have consistently shown an increase in student performance in undergraduate courses in science, technology, engineering, and mathematics disciplines (Freeman et al., 2014; Prince and Felder 2006; Prince 2004). Several researchers have suggested that active learning methods may be especially useful in allowing students to better understand sustainability principles (Huntzinger et al., 2007; Korkmaz, 2011; Siller, 2001). The case-based urban water stakeholder simulation module designed in this study employs several pedagogies to promote active student learning.

\subsubsection{Case-Based Learning}

Inductive learning begins with a context for learning rather than fundamental theories and concepts. Inquiry-based learning is an inductive learning method based on the constructivist theory of learning that knowledge is constructed by the learner. Students assume responsibility for the learning process by engaging in experiences and experiments to solve a problem. Inductive teaching strategies provide students with opportunities to engage in experience-driven learning within collaborative learning environments (Prince and Felder, 2006). Case-based learning is a type of inductive learning method in which students are presented with the context of a case study with complex, ill-defined problems to consider. Case-based learning goes beyond the constructivist theory of learning in that it defines a model of cognition that can be turned to for advice and for predictions that can be simulated to test ideas, thus allowing students to draw productive lessons from a case and transfer their knowledge to future situations (Jonassen and Land, 1999). Case-based methods have also been shown to be a preferred inductive learning style among instructors and students (Srinivasan et al., 2007).

To design case-based modules as effective inductive learning tools, the context of the case is described but the actual decisions made are withheld so students can inductively develop their own solutions to the problems presented (Lynn, 1999). The following steps to structure case-based discussions have been suggested to optimize the student learning experience in case-based environments (Kardos, 1979): (1) review of the case content, (2) statement of problems, (3) collection of relevant information, (4) development of alternatives, (5) evaluation of alternatives, (6) selection of a course of action, and (7) evaluation of solutions and review of actual case outcomes.

\subsubsection{Learning Cycle-Based Instruction}

The steps proposed for case-based learning closely follow several learning cycle models. For instance, Kolb's experiential learning theory, which asserts that experiences play a key role in the learning process, suggests that student learning occurs in two stages: grasping experiences (through a concrete 
experience phase and an abstract conceptualization phase) and transforming experiences (through a reflective observation phase and an active experimentation phase) (Kolb, 1984). Based on this theory, Kolb postulates that complete learning occurs when students engage in all four phases of a learning cycle, and that instructors can promote complete learning by designing course materials to encourage students to complete all learning cycle phases (Kolb et al., 2001).

\section{MODULE DESIGN AND IMPLEMENTATION}

The module employed in this study was designed to make use of case-based learning methods within a learning-cycle-based instructional framework. The seven steps suggested for case study design by Kardos (1979) were used in the design of the urban water stakeholder simulation module, as summarized in Table 1.

Table 1: Module design components

\begin{tabular}{|c|c|c|}
\hline $\begin{array}{l}\text { Steps for Case-Based } \\
\text { Module Development }\end{array}$ & Module Features & Pedagogy Elements \\
\hline $\begin{array}{l}\text { (1) Review of the case } \\
\text { content }\end{array}$ & $\begin{array}{l}\text { Mini lecture, videos and discussions of } \\
\text { stormwater engineering design and } \\
\text { Onondaga County context }\end{array}$ & $\begin{array}{l}\text { Grasping experiences } \\
\text { through concrete experience } \\
\text { and abstract } \\
\text { conceptualization }\end{array}$ \\
\hline (2) Statement of problem & $\begin{array}{l}\text { Problem statement: As a member of a key } \\
\text { stakeholder group in Onondaga County, } \\
\text { what type of technologies or solutions would } \\
\text { you consider and why? }\end{array}$ & Case-based problem \\
\hline $\begin{array}{l}\text { (3) Collection of relevant } \\
\text { information, and } \\
\text { (4) Development of } \\
\text { alternatives }\end{array}$ & $\begin{array}{l}\text { Stakeholder simulation activity: student } \\
\text { group discussion aided by floating } \\
\text { facilitators }\end{array}$ & $\begin{array}{l}\text { Student collaboration; } \\
\text { transforming experiences } \\
\text { primarily through active } \\
\text { experimentation }\end{array}$ \\
\hline $\begin{array}{l}\text { (5) Evaluation of } \\
\text { alternatives, and } \\
\text { (6) Selection of a course } \\
\text { of action }\end{array}$ & $\begin{array}{l}\text { Environmental, economic, social and ethical } \\
\text { considerations used to evaluate each set of } \\
\text { proposals }\end{array}$ & $\begin{array}{l}\text { Student collaboration; } \\
\text { transforming experiences } \\
\text { primarily through reflective } \\
\text { observation }\end{array}$ \\
\hline $\begin{array}{l}\text { (7) Evaluation of solutions } \\
\text { and review of actual case } \\
\text { outcomes }\end{array}$ & $\begin{array}{l}\text { Summary of actual changes to Onondaga } \\
\text { County's stormwater management plans }\end{array}$ & $\begin{array}{l}\text { Grasping experiences } \\
\text { through abstract } \\
\text { conceptualization }\end{array}$ \\
\hline
\end{tabular}

\subsection{Case Selection and Context}

Preparation for case-based learning is very demanding, as instructors must be intimately familiar with the history and current state of decisions related to the case in order to actively respond to questions during the case (Kardos, 1979). This case was selected based on the authors' expertise on sustainable urban water systems and depth of knowledge on stakeholder perspectives (Flynn et al., 2014; Flynn and Davidson, 2015). The context of the case takes place in Onondaga County, located in Central New York. Onondaga County operates a combined sewer system and must provide a control plan to manage combined sewer overflows (CSOs). Most municipal CSO control plans in the U.S. make use of traditional "gray infrastructure" solutions, or CSO control technologies that either enhance or supplement existing sewer infrastructure, which tend to be large in scale and cost. Implementing only gray infrastructure systems for urban stormwater management is neither sustainable nor sufficiently resilient to accommodate climatic changes (Novotny et al., 2010; Pyke et al., 2011). Conversely, urban stormwater systems that include green infrastructure technologies are recognized as a more sustainable management approach. Onondaga County's original CSO management plans included multiple expensive and gray infrastructure technologies that were considered invasive by local community members. While all major regulating and regulated parties were directly involved in the project planning, 
several important stakeholder groups were not. Over time, the environmental injustices stemming from this exclusion led to the social unrest of many groups in Onondaga County, particularly the Onondaga Nation and the residents of the Southside neighborhood (Perreault et al., 2012).

\subsection{Implementation of Module}

The implementation of the module took place during a single 80 minute lecture period. Instruction began with grasping experiences through a mini lecture on why stormwater engineering design is both necessary and inherently complex. Early module content also described available technology options and the stakeholders that are affected by each option. Urban stormwater management issues were reviewed and local contextualization was provided with videos of recent localized flooding on campus and the surrounding neighborhoods. The module continued with a discussion of these issues and how the framing of water issues impacts the goals, system boundaries and specific solutions. Stakeholder engagement processes were introduced and a variety of different stakeholder groups involved with and affected by municipal stormwater management decisions were discussed. Students were then presented with the context of the Onondaga County case study. Recent changes to Onondaga County's stormwater management plans to include extensive green infrastructure technologies were intentionally left out of the module to elicit original student ideas as the module progressed.

The case-based simulation activity was designed to promote the active experimentation phase of learning, as students explored how they would advocate for particular engineering solutions while representing a certain stakeholder group within Onondaga County, and considered what consequences would occur if their solutions were chosen. Background on the case and on each stakeholder group was presented to the students and is shown in Table 2. The four stakeholder groups described in Table 2 were selected from the multiple stakeholders involved with this case. The class was divided into four equal groups, each representing one stakeholder group. Potential solutions using gray and green infrastructure were reviewed, as summarized in Table 3. Information on technology options was presented for the time period of 2007-2008, when green infrastructure technologies were acknowledged as a potential alternative to gray infrastructure technologies but not widely implemented. Students were then asked to answer the following question with their group: As a member of a key stakeholder group in Onondaga County, what type of technologies or solutions would you consider and why?

Table 2: Stakeholder goals and concerns

\begin{tabular}{ll}
\hline Stakeholder Group & Primary Goals and Concerns \\
\hline $\begin{array}{l}\text { Onondaga County } \\
\text { Government }\end{array}$ & $\begin{array}{l}\text { Must meet consent judgment criteria to treat or mitigate 400 million gallons of } \\
\text { annual CSO volume and decrease bacteria, phosphorus and trash loadings } \\
\text { to Onondaga Lake using proven technologies in a cost effective manner }\end{array}$ \\
\hline Engineering firms & $\begin{array}{l}\text { Must design proven and cost effective stormwater management solutions to } \\
\text { meet the needs of their customer (Onondaga County) }\end{array}$ \\
\hline Southside residents & $\begin{array}{l}\text { Several concerns: proximity of invasive infrastructure projects, localized and } \\
\text { basement flooding, construction disruptions, aesthetics, recreation, health }\end{array}$ \\
\hline Onondaga Nation & $\begin{array}{l}\text { Lake is a sacred site; Onondaga Nation follows a vision of environmental } \\
\text { stewardship and cooperative resource management; fish from Onondaga } \\
\text { Lake was once a source of food }\end{array}$ \\
\hline
\end{tabular}

Table 3: Technological aspects of gray and green infrastructure

\begin{tabular}{lll}
\hline $\begin{array}{l}\text { Technological } \\
\text { Aspect }\end{array}$ & Gray Infrastructure & Green Infrastructure \\
\hline Materials & Human manufactured materials & $\begin{array}{l}\text { Human manufactured and natural } \\
\text { materials }\end{array}$ \\
\hline
\end{tabular}




\begin{tabular}{lll}
\hline Benefits & $\begin{array}{l}\text { Single purpose technologies for } \\
\text { stormwater mitigation and treatment }\end{array}$ & $\begin{array}{l}\text { Multifunctional technologies with } \\
\text { multiple environmental and social } \\
\text { benefits }\end{array}$ \\
\hline $\begin{array}{l}\text { Distribution and } \\
\text { capacity }\end{array}$ & $\begin{array}{l}\text { Large capacity to centrally treat and } \\
\text { transport stormwater }\end{array}$ & $\begin{array}{l}\text { Varied capacities to treat and manage } \\
\text { stormwater through a diffuse network }\end{array}$ \\
\hline System integration & $\begin{array}{l}\text { Concentrates stormwater and } \\
\text { pollutants to be treated with chemicals }\end{array}$ & $\begin{array}{l}\text { Complementary to existing } \\
\text { infrastructure; systems-thinking design }\end{array}$ \\
\hline
\end{tabular}

Several possible considerations were provided to the students, including economic limitations and opportunities, political and community culture, current ecosystem conditions, current state of existing infrastructure, legal constraints, and current and future climatic conditions. Students were provided ample time to discuss the various technology options within their groups. A floating facilitator model was employed with four instructors moving from group to group during the discussion period to respond to student questions. Each facilitator had studied different aspects of this case over multiple years and was able to provide robust answers to student questions. After the discussion, students were asked to advocate for their technology selection and to provide support based on the goals and concerns of their stakeholder group. The class ended with an open discussion of the various proposals and a brief presentation of the actual solutions implemented in Onondaga County.

\subsection{Formative Assessment Tool}

A formative assessment tool was administered directly following the implementation of the module to provide feedback on its effectiveness as a teaching tool. The assessment also provided information on students' perceptions of their learning, as well as their overall enjoyment of the module activities and structure. The formative assessment tool included two parts. The first section used a three point Likert scale (Strongly Agree, Agree or Disagree) to assess student perceived level of understanding on several topics after the module; the second included two open ended questions to elicit student comments on their satisfaction of the module.

\section{RESULTS}

\subsection{Formative Assessment Results: Part 1}

Results for Part 1 are presented in Table 4. Previous to the implementation of this module, urban hydrology issues were covered in several lectures with specific examples of existing technological solutions. However, stakeholder concerns and stormwater issues in Onondaga County (i.e., the Syracuse area) were not directly addressed. Following the module implementation, 95\% of students agreed or strongly agreed that they had a better understanding of how course concepts apply to real world cases, and $96 \%$ felt that the module helped them to better understand urban water problems in Syracuse, NY. Anecdotal evidence suggests that most of the students in the course are not from the Central New York area and therefore would be uninformed of local ongoing issues. This response is of particular importance to the instructors who encourage their students to relate course material to the world around them. Additionally, $86 \%$ of students agreed or strongly agreed that they better understood stakeholder involvement in engineering decisions following this module. This result is also notable, as increasing students' ability to understand the complexities of engineering decisions was a primary objective for the module. 
Table 4: Evaluation of learning activities

\begin{tabular}{lccc}
\hline Question & Disagree & Agree & Strongly Agree \\
\hline $\begin{array}{l}\text { As a result of today's activities, I have a better understanding } \\
\text { of how concepts learned in this course apply to the real world. }\end{array}$ & $5 \%$ & $75 \%$ & $20 \%$ \\
\hline $\begin{array}{l}\text { As a result of today's activities, I have a better understanding } \\
\text { of how different stakeholders influence engineering decisions. }\end{array}$ & $14 \%$ & $59 \%$ & $27 \%$ \\
\hline $\begin{array}{l}\text { As a result of today's activities, I have a better understanding } \\
\text { of urban water problems in the Syracuse area. }\end{array}$ & $4 \%$ & $60 \%$ & $36 \%$ \\
\hline I enjoyed today's activities. & $25 \%$ & $57 \%$ & $18 \%$ \\
\hline
\end{tabular}

\subsection{Formative Assessment Results: Part 2}

Of the students who completed the assessment tool, 23 included useful comments in the open ended section. Two of the instructors categorized the open comments based on common themes and language that students used to describe their experiences in the module. The first open ended question asked what the students enjoyed most about the class activity. These comments were classified into seven groups, with some comments being included in multiple groups, as shown in Figure 1. Many students mentioned that they enjoyed working in groups and enjoyed learning about the various interests of the different stakeholders.

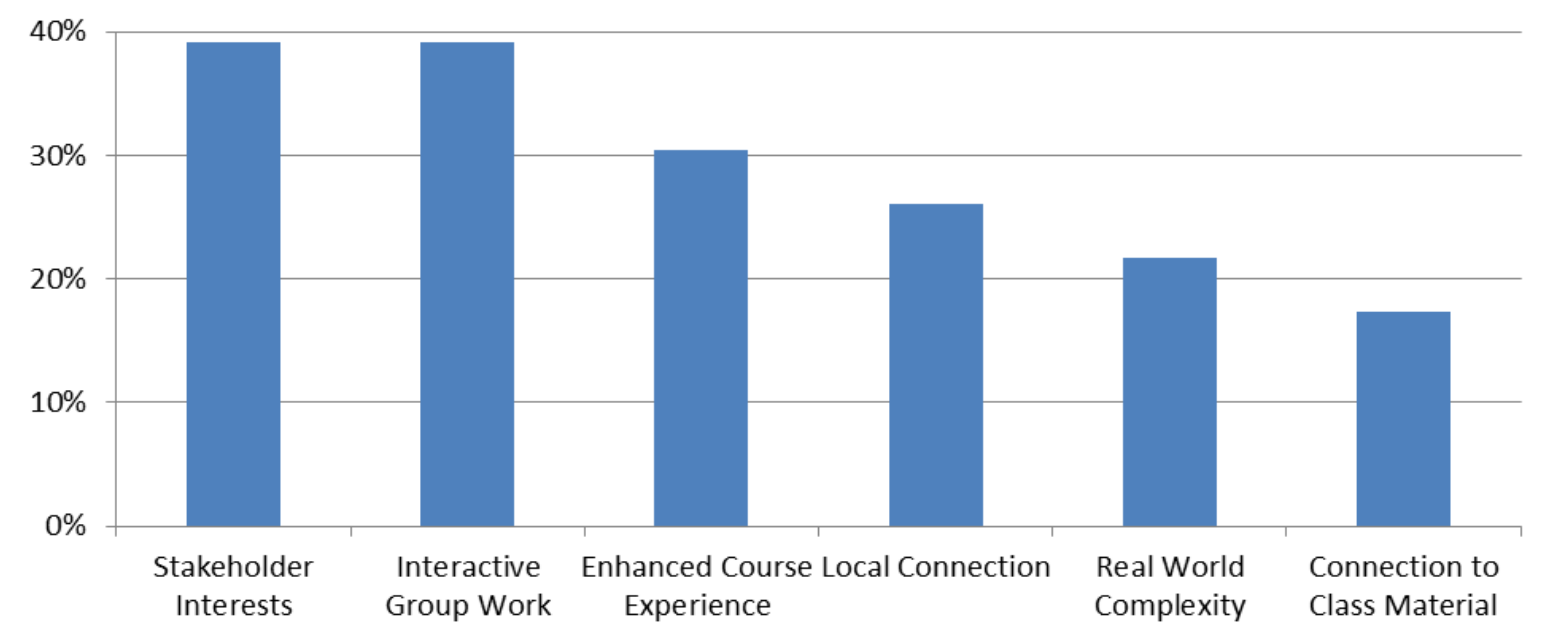

Figure 1: Student responses to "What did you enjoy most about today’s activities?"

Several comments from the first question of Part 2 also indicated an increase in student motivation to continue investigating stormwater engineering issues. Two such comments are included below:

"I thought the lecture was well done and I found it to be engaging, interesting and extremely useful. This was possibly the most useful lecture I have here at Syracuse and reminded me why I chose engineering."

"Maybe make this into a 2 day activity, so people can come to the next class with a little more knowledge and do some research to the problems and think more thoroughly on solutions." 
The second open ended question of Part 2 asked what the students thought should be improved about the module. Sixteen useful responses to this question were classified into three groups, with some comments being included in multiple groups, shown in Figure 2. Nine of the responses included comments on group size and limited interaction within the groups. Six students requested more structure to the module and more information. Just over one third of the responses included a comment on logistics of the class, including issues related to the classroom layout and time constraints.

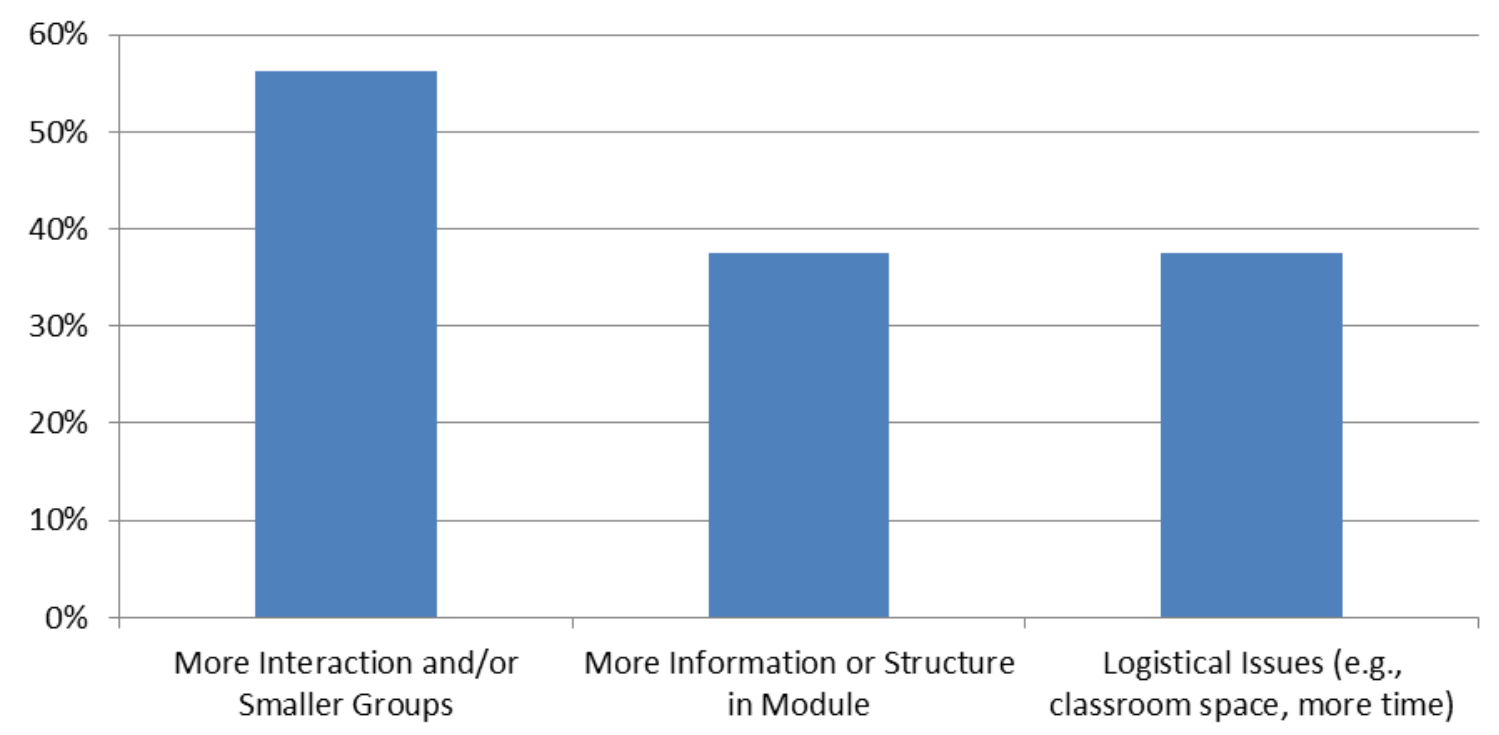

Figure 2: Student responses to "What suggestions do you have for improvement of today's activities?

\section{CONCLUSIONS AND ONGOING WORK}

In order to encourage active student engagement in learning of urban stormwater management practices, a case-based module was developed and implemented in a sophomore civil and environmental engineering course. Assessment results suggest that the module effectively increased student understanding of complex decision making processes required of engineers. The instructors observed high levels of student involvement and engagement in the material throughout the module, particularly during the simulation activity. Students enjoyed the collaborative learning activities and focus on a local engineering case study involving diverse stakeholder concerns. Several modifications will be applied to the module in response to student suggestions. For instance, additional stakeholder groups will be included, such as multiple engineering firms, environmental organizations, and a local business council, in order to allow for smaller student groups while also creating a more realistic simulation activity. Moreover, several student comments from the assessment tool suggested the need for additional reflective observation time. In future iterations, the module will be spread out over two lectures and one recitation period. An innovative classroom space will be completed within the college to allow for enhanced interaction of small groups within a large classroom setting. Some level of gamification is being considered for the simulation activity, which will take place during the second lecture period. Additional work on this module aims to further engage students with a local, real-world, complex situation both to forge better and more creative engineers and to enhance student learning in the classroom setting. 


\section{References}

Allenby, Brad, Cynthia Folsom Murphy, David Allen, and Cliff Davidson. 2009. "Sustainable Engineering Education in the United States." Sustainability Science, 4 (1): 7-15.

Davidson, Cliff I., H. Scott Matthews, Chris T. Hendrickson, Michael W. Bridges, Braden R. Allenby, John C. Crittenden, and Yongsheng Chen. 2007. "Viewpoint: Adding Sustainability to the Engineer's Toolbox: A Challenge for Engineering Educators." Environmental Science \& Technology, 41 (14): 4847-49.

Flynn, Carli D., and Cliff I. Davidson. 2015. "The Classification of Factors Influencing Green Infrastructure Adoption in Onondaga County, NY Using the Social-Ecological System Framework." In Preparation to Be Submitted May 1, 2015.

Flynn, Carli D., Cliff I. Davidson, and Joanne Mahoney. 2014. "Transformational Changes Associated with Sustainable Stormwater Management Practices in Onondaga County, New York." ICSI 2014: Creating Infrastructure for a Sustainable World. American Society of Civil Engineers, Long Beach, CA, USA. 1:89-100.

Freeman, Scott, Sarah L. Eddy, Miles McDonough, Michelle K. Smith, Nnadozie Okoroafor, Hannah Jordt, and Mary Pat Wenderoth. 2014. "Active Learning Increases Student Performance in Science, Engineering, and Mathematics." Proceedings of the National Academy of Sciences, 111 (23): 8410-15.

Huntzinger, Deborah N., Margot J. Hutchins, John S. Gierke, and John W. Sutherland. 2007. "Enabling Sustainable Thinking in Undergraduate Engineering Education." International Journal of Engineering Education, 23 (2): 218.

Jonassen, David H., and Susan M. Land. 1999. "Theoretical Foundations of Learning Environments." Routledge, Oxford, UK.

Kardos, Geza. 1979. "Engineering Cases in the Classroom." Proceedings of the National Conference on Engineering. http://www.civeng.carleton.ca/ECL/cclas.html.

Kolb, David A. 1984. Experiential Learning: Experience as the Source of Learning and Development. Prentice-Hall, Englewood Cliffs, NJ, USA.

Kolb, David A., Richard E. Boyatzis, Charalampos Mainemelis, and others. 2001. "Experiential Learning Theory: Previous Research and New Directions." Perspectives on Thinking, Learning, and Cognitive Styles, 1: 227-47.

Korkmaz, Sinem. 2011. "Case-Based and Collaborative-Learning Techniques to Teach Delivery of Sustainable Buildings." Journal of Professional Issues in Engineering Education and Practice, 138 (2): 139-44.

Lynn, Laurence E. 1999. Teaching and Learning with Cases: A Guidebook. CQ Press.

Nair, Indira. 1997. "Decision Making in the Engineering Classroom." Journal of Engineering Education, 86 (4): 349-56.

Novotny, Vladimir, Jack Ahern, and Paul Brown. 2010. Water Centric Sustainable Communities: Planning, Retrofitting and Building the next Urban Environment. John Wiley \& Sons, Hoboken, NJ, USA.

Perreault, Thomas, Sarah Wraight, and Meredith Perreault. 2012. "Environmental Injustice in the Onondaga Lake Waterscape, New York State, USA." Water Alternatives 5 (2): 485-506.

Prince, Michael. 2004. "Does Active Learning Work? A Review of the Research." Journal of Engineering Education, 93 (3): 223-31.

Prince, Michael J., and Richard M. Felder. 2006. "Inductive Teaching and Learning Methods: Definitions, Comparisons, and Research Bases." Journal of Engineering Education, 95 (2): 123-38.

Pyke, Christopher, Meredith P. Warren, Thomas Johnson, James LaGro Jr, Jeremy Scharfenberg, Philip Groth, Randall Freed, William Schroeer, and Eric Main. 2011. "Assessment of Low Impact Development for Managing Stormwater with Changing Precipitation due to Climate Change." Landscape and Urban Planning, 103 (2): 166-73.

Siller, Thomas J. 2001. "Sustainability and Critical Thinking in Civil Engineering Curriculum." Journal of Professional Issues in Engineering Education and Practice, 127 (3): 104-8.

Srinivasan, Malathi, Michael Wilkes, Frazier Stevenson, Thuan Nguyen, and Stuart Slavin. 2007. "Comparing Problem-Based Learning with Case-Based Learning: Effects of a Major Curricular Shift at Two Institutions." Academic Medicine, 82 (1): 74-82. 